\title{
Developing a Code of Practice for Learning Analytics
}

\author{
Niall Sclater \\ Jisc / Sclater Digital, UK \\ analytics@sclater.com
}

\begin{abstract}
Ethical and legal objections to learning analytics are barriers to development of the field, thus potentially denying students the benefits of predictive analytics and adaptive learning. Jisc, a charitable organization that champions the use of digital technologies in UK education and research, has attempted to address this with the development of a Code of Practice for Learning Analytics. The Code covers the main issues institutions need to address in order to progress ethically and legally. This paper outlines the extensive research and consultation activities carried out to produce a document that covers the concerns of institutions and, critically, the students they serve. The resulting model for developing a code of practice includes a literature review, setting up appropriate governance structures, developing a taxonomy of the issues, drafting the code, consulting widely with stakeholders, as well as publication, dissemination, and embedding it in institutions.
\end{abstract}

Keywords: Learning analytics, ethics, privacy, legal issues, code of practice

\section{$1 \quad$ INTRODUCTION}

Ethical and legal issues are almost invariably raised whenever the use of learning analytics is proposed in institutions. Concerns are expressed in particular about potential invasions of student privacy arising from the misuse of their data, and about the adverse consequences that might arise from monitoring their activity and predicting their future academic success. Such issues have become impediments to the development and rollout of learning analytics, in some institutions halting the implementation of learning analytics completely. The most notorious example is inBloom, an initiative developed with $\$ 100$ million funding from the Gates and Carnegie Foundations, which developed mechanisms for storing large amounts of data relating to US schoolchildren and their learning activities. In the post-Snowden era, sensitivities around privacy were running high, communications were badly handled, and families and privacy advocates ultimately forced the closure of the programme (K.N.C., 2014).

Soon afterwards, Facebook's famous "mood experiment" placed positive and negative items and images in the timelines of 700,000 users to find out if these would affect users' moods. This resulted in a huge backlash from users and extensive negative media coverage, forcing changes to Facebook's research methods and policies (Shroepfer, 2014). While concerns about privacy, data protection, and ethics raised by students and staff at educational institutions are generally valid and must be addressed, the ensuing hiatus means that learners are being denied the potential benefits of learning analytics that can help to identify areas for improvement and ultimately make the difference between completing their course and dropping out.

Using personal data to present analytics and inform interventions that may significantly affect students' 
lives does, of course, bring with it serious responsibilities. King and Richards (2014) argue that we are in a critical window and that whatever ethical practices are established now in the field of big data will affect notions of acceptability for years to come. The sheer amount of data that can now be collected on individuals, and the insight that can be gained from its analysis, enable far more to be learnt about people than was ever anticipated (PCAST, 2014). Algorithms now exist that can discover things about you before you know them yourself. The implications for the privacy of learners, and the potential for misuse of the data collected and the analytics performed on it, necessitate the use of carefully considered policies that help institutions to act ethically, stay within the law, and minimize adverse impacts on individuals. Such frameworks, however, should not unnecessarily hold up the progress being made in the field of learning analytics that promises real benefits for students and institutions.

Educational researchers have been arguing for some time for the need for a set of principles or a code of ethics as the field of learning analytics develops. Ferguson (2012) recommends an ethical framework to help institutions make decisions regarding the ownership and stewardship of learners' data. However, Pardo and Siemens (2014) suggest this will be difficult as institutions already struggle to define privacy policies in other areas. Berg (2013) believes that without a code of ethics, institutions may carry out analytics in arbitrary ways, thus reducing consistency and fair treatment for students. He proposes that such a document would help to alleviate differences in approaches to dealing with analytics by teachers and senior managers. Add into the mix the viewpoint of students who may not wish to have their personal data collected, let alone acted upon through an "intervention," and you have a toxic mix of expectations - unless common understanding can be achieved through mutually agreed policies. Indeed, without addressing the ethical issues, users (both employees and students) may actively resist the introduction of learning analytics (Greller \& Drachsler, 2012; Siemens, 2012).

Students are increasingly accustomed to having their data collected by commercial organizations or government agencies for arguably far more intrusive purposes than learning analytics. They may therefore show little resistance to the collection and use of their data by trusted educational institutions for the purposes of enhancing their education. However, developing a clearly articulated set of principles to handle student data and any interventions appropriately can be a preventative measure, pre-empting backlashes from users such as those experienced by InBloom and the Facebook mood experiment. It has been noted too that employees usually prefer to work for organizations committed to ethical standards, and that consumers like to buy from companies with "strong records of adherence to standards of conduct and socially sensitive behavior" (PABC, 2007). It is likely that employees and students of educational institutions are no different in this regard; arguably, universities and colleges have an even stronger imperative to act ethically and legally for the benefit of learners, and to demonstrate clearly how they are doing so.

Transparency is key here: it is in the interests of students, staff, and institutions that the uses to which learning analytics will be put are explained as clearly as possible. There is a risk, as Slade \& Prinsloo (2013) point out, that learning analytics will fail to be adopted successfully unless perceptions are managed carefully. Other industries have already developed codes of practice for the use of data and analytics, as 
have various professions and communities of practice within education. It is worth examining the benefits to organizations listed by the UK Information Commissioner's Office of following its code of practice for personal information online (ICO, 2010):

- Greater trust and a better relationship with the people you collect information about

- Reduced reputational risk caused by the inappropriate or insecure processing of personal data

- Better take-up of online services, meaning economic savings and greater convenience for customers

- Minimized risk of breaches and consequent enforcement action by the Information Commissioner or other regulators

- Gaining a competitive advantage by reassuring the people you deal with that you take their privacy seriously

- Increasing people's confidence to provide more valuable information, because they are reassured that it will be used properly and kept securely, and

- Reduced risk of questions, complaints and disputes about your use of personal data.

Jisc, the organization responsible for many aspects of IT infrastructure and learning technology in UK higher and further education, has been leading an initiative to promote the effective use of learning analytics (Sclater, 2014a). Working closely with stakeholders as part of a "co-design" process, ${ }^{1}$ tackling issues relating to privacy and ethics was identified early on as a priority. It was felt that a Code of Practice for Learning Analytics (Sclater \& Bailey, 2015) was essential in order for progress to be made. This would identify the main legal and ethical barriers to progress and suggest ways for institutions to overcome them.

The development of Jisc's Code of Practice has involved five stages:

1. An extensive literature review of the legal and ethical issues around learning analytics

2. The formation of an advisory group to oversee the development of the Code of Practice

3. The development of a taxonomy of ethical, legal, and logistical issues - and its validation with national and international experts

4. The drafting of the Code of Practice - and its validation with stakeholders across the sector

5. The population of an accompanying website with further guidance and case studies.

This paper discusses how these stages have contributed to a code of practice informed by the literature and by experts in the field, achieving consensus through extensive consultation, and the involvement of students. It also defines a model for this process and briefly outlines how this could be used for the development of other codes of practice.

\footnotetext{
1 "Co-design" is Jisc's collaborative technology innovation model that uses customer priorities to identify new opportunities and address pressing issues in education.
} 


\section{CARRYING OUT THE LITERATURE REVIEW}

For the literature review (Sclater, 2014b), publications from many different authors and organizations were gathered. Material was drawn from eighty-six documents, more than a third of them published within the preceding year, from sources including:

- The literature around learning analytics that makes explicit reference to legal and ethical issues

- Articles and blogs around the ethical and legal issues of big data

- A few papers that concentrate specifically on privacy

- Relevant legislation, in particular the European Data Protection Directive 1995 and the UK Data Protection Act 1998

- Related codes of practice from education and industry

Expressing issues as questions can be a useful way of making complex issues more concrete. Ninety-three questions from the literature that authors had posed directly were incorporated. The categorizations of these highlighted in the word cloud shown in Figure 1 give an instant flavour of the main concerns around the implementation of learning analytics being raised by researchers and practitioners.

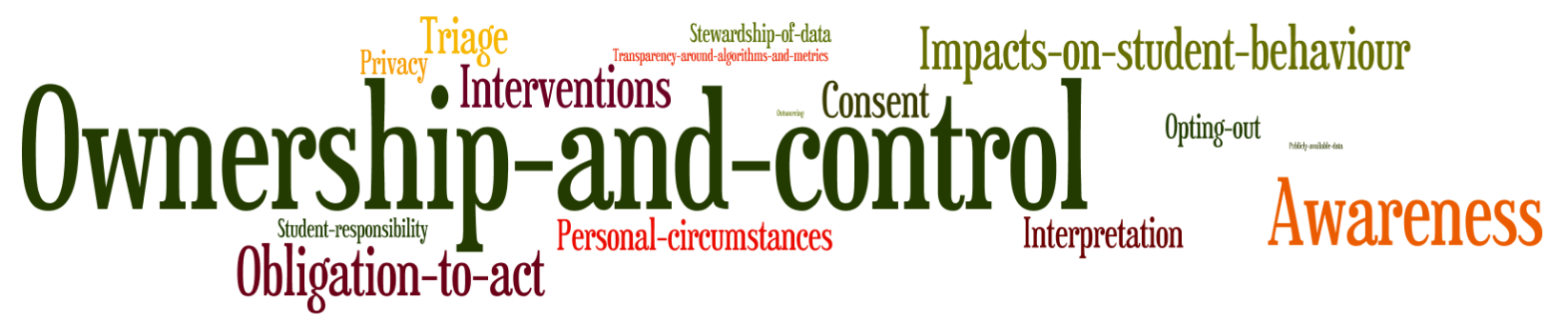

Figure 1: Main concerns in the literature around learning analytics as identified by Sclater (2014b).

At the end of the literature review, sixteen codes of practice and lists of ethical principles from related fields were reviewed. It was found that the main concepts their authors attempted to embody were transparency, clarity, respect, user control, consent, access, and accountability - all of which are highly relevant and correspond with the concerns being raised by researchers and practitioners in the field of learning analytics.

\section{DELIBERATIONS OF THE ADVISORY GROUP}

An important part of the process for developing the Code was the formation of an advisory group with fifteen members from the higher and further education sectors (Sclater, 2015a). The group included a pro vice-chancellor, academics with expertise in policy, ethics, and learning analytics, senior IT staff, a legal expert, and a representative from the UK's National Union of Students (NUS). ${ }^{2}$ Members were able to advise on the approach to producing the Code, the areas to be covered, ways to gain further validation

\footnotetext{
${ }^{2}$ The institutions represented were Croydon College, Edinburgh University, Huddersfield University, Lancaster University, London South Bank University, Loughborough University, Jisc, National Union of Students, and The Open University.
} 
from the community, dissemination and adoption. It was agreed that the main purpose of the Code would be to help remove barriers to the adoption of learning analytics, and that it should provide a focus for institutions to deal with the many legal and ethical hurdles that they were encountering. Alongside a concise summary document, the guidance could be presented as an evolving, dynamic site rather than a lengthy one-off document that would be less likely to be read, let alone adhered to. Members also agreed to critique the Code as it was being developed and to consider piloting it at their own institutions.

\subsection{Methodology and Approaches}

Some documents of this nature take a particular methodological or philosophical stance. For instance, Slade and Prinsloo's (2013) socio-critical approach - where learning analytics is viewed as a "transparent moral practice" and students are seen as co-contributors - has influenced the Open University's Policy on Ethical Use of Student Data (Open University, 2014). The advisory group suggested that the Code's emphasis would be "positive, realistic and facilitative" and that it should emphasize that learning analytics is primarily for the benefit of students.

The group considered that one of the main challenges of developing the Code would be to strike a balance between a paternalistic approach and respecting students' privacy and autonomy. An approach that put the needs of learners at the heart of the Code was thought likely to result in a better, more widely adopted document and help to allay the fears of students and institutions, hence facilitating the uptake of learning analytics. The inclusion of the NUS in this group was therefore particularly welcome.

Would a separate code of practice or "bill of rights for learning analytics" owned by and for students help to gain acceptance? Or could this diverge so much from the one representing institutional concerns that it would exacerbate the differences and create conflict? Combining all interests in one document would require a balanced approach and a series of compromises but hopefully encourage mutual understanding, result in a usable Code, and move the field of learning analytics forward collaboratively.

The advisory group concluded that a single document clearly setting out the rights and responsibilities of students, institutions, and staff would be preferable. Explaining what the Code means in practice however would require separate advice for different stakeholders. At institutions, the Code should ideally link closely with documents such as the student charter, and ensure buy-in from the student union.

Another issue raised was whether the Code could be at a sufficiently high level to meet the needs of all institutions while remaining specific enough to provide genuinely helpful guidance. Researchers and senior managers with responsibility for implementing learning analytics at a range of institutions had been approached earlier to review the development of learning analytics at their institutions (Sclater, 2014d). From a series of semi-structured interviews, it had become clear that the potential uses of learning analytics and the concerns raised varied widely across institutions. The advisory group thought that the Code should be fairly high level in order to prove useful to all, but should be backed up by case studies and examples of how institutions have dealt with particular issues. The case studies could be presented 
alongside the Code - for each principle, there could be examples of good practice.

Another question raised was whether institutions should be encouraged to adopt the Code wholesale, and therefore be able to claim conformance with it, or to use it more as a checklist of issues to be considered and customized to fit their own institutional policies. The latter approach seemed more likely, and several universities have already suggested that they will use it as the basis for their own learning analytics policies.

Particular concern was expressed that the Code must reflect the human context and the need for intermediation of learning analytics by staff. This is a common ethical theme in the literature. However, a representative from The Open University said that the sheer scale of that institution makes it unfeasible to use human intermediation for many of the potential uses of learning analytics. Meanwhile there was a strong recommendation that the language used to present analytics to students should be carefully considered and that data should only be exposed when institutions have mechanisms in place to deal with the effect on students. The potential impact of analytics on the educator also needed to be reflected in the Code.

\subsection{An Appropriate Format for the Code of Practice}

Most codes of practice are textual documents, normally provided in PDF. The members felt that a document outlining the principles needed to be provided in order to present it to institutional committees but that an interactive website containing case studies, perhaps in the form of videoed interviews with staff and students, would be welcome.

Many codes of practice or "codes of ethics" are extremely lengthy and somewhat uninspiring papers stretching to thirty pages or more. One of the more readable examples is the Respect Code of Practice for Socio-Economic Research (RESPECT Project, 2004). It is concise - only four pages - and reasonably visually appealing, therefore arguably more likely to be read and absorbed by busy people than some of the longer codes. However, given the large number of issues identified in the literature review, four pages were thought unlikely to be sufficient.

The agreed approach was to back up a concise summary document with more detailed online guidance for each of the areas. The literature review covers most of the ethical and legal issues likely to be of concern to students and to institutions when deploying learning analytics; the word clouds in the review could help prioritize the main areas to be included in the document. Supporting content - e.g., videoed interviews - could be developed subsequently, assist in raising awareness of the Code, provide examples of how it is being implemented, and help to keep it up to date. Discussion forums could be included on each topic, enabling users to raise further issues, and others to provide advice on how they have tackled that challenge. This would need some ongoing promotion, facilitation, and moderation by Jisc and/or members of the community. 


\subsection{Dissemination and Rollout}

A sense of ownership by institutions and by students was considered essential to ensure adoption. How could this best be achieved? A range of stakeholder organizations was proposed for consultation and a number of possible events to piggyback on were proposed as dissemination opportunities. Several members said they would be keen to try piloting the Code at their institutions too. It was also suggested that vendors should be included in the consultation process. It might help them when making development decisions, encouraging them for instance to build consent systems into their products. The Code could help to ensure that safeguards, such as ensuring privacy, are incorporated without holding back innovation.

One member of the advisory group suggested that it would be useful to better understand the processes inside institutions for getting academic policies adopted, as this would be key to uptake. In addition, some events specifically around the Code could be held, and papers delivered at relevant conferences. It was felt that the Code should be launched with some fanfare at a larger event to increase awareness and potential take-up.

\section{DEFINING AND VALIDATING A TAXONOMY OF ETHICAL, LEGAL, AND LOGISTICAL ISSUES}

A few events have centred around issues of ethics and privacy in learning analytics, notably a workshop organized by LACE and SURF in Utrecht, Netherlands, in October 2014 (Sclater, 2014c) and a preconference event with peer-reviewed submissions at the Learning Analytics and Knowledge Conference (LAK '15) in Poughkeepsie, USA. ${ }^{3}$ In such discussions at conferences and within institutions, the same issues are continually raised but have generally already been covered somewhere in the growing collection of publications on learning analytics. Sometimes the issue is expressed differently but boils down to the same underlying problem. The literature review produced for the Code of Practice (Sclater, 2014b) is a large and unwieldy document, so the issues and questions detailed in it were distilled from the text line by line into a more succinct tabular format. The word clouds in the literature review were used as a basis for grouping the issues.

The resulting taxonomy in Table 1 includes eighty-six distinct issues (Sclater, 2015c). Each is given a name and expressed as a question that attempts to capture the issue concisely. Many of the questions cannot of course be answered simply; almost all could be responded to with "It depends..." An attempt was made to classify them as either primarily ethical or primarily legal in nature. Most have both an ethical and a legal dimension; as laws are often underpinned by ethics, this is not surprising. While some were referred to in the literature as ethical issues, they were however related more to the logistics of carrying out learning analytics in institutions than doing what's ethically right or keeping within the law. Thus, what started out as a collection of ethical and legal issues became a list incorporating a number of logistical

\footnotetext{
${ }^{3}$ Details of the event are at http://www.laceproject.eu/ethics-privacy-learning-analytics/
} 
issues as well.

Jisc, Apereo Foundation, and the LACE Project held a workshop in Paris in February 2015 (Sclater, 2015b) to discuss the ethical and legal issues of learning analytics, focusing on the draft taxonomy. Twelve participants from France, Germany, the Netherlands, and the UK, primarily from academic backgrounds, worked together to validate and refine the list of issues and comment on the approach. As a result, the taxonomy in Table 1 was re-ordered to reflect a lifecycle view of learning analytics, moving from issues of ownership and control to seeking consent from students, encouraging transparency, maintaining privacy, ensuring validity in the data and the analytics, enabling student access to the data, carrying out interventions appropriately, minimizing adverse impacts, and stewarding the data.

The Paris workshop group suggested scoring the issues based on their importance and started the process of rating them on a scale of 1 to 5 , highlighting the most important ones. The scale was subsequently reduced to three points, roughly equating to 1) Critical, 2) Important, 3) Less important or may not arise. The ratings are the subjective view of the group and the author based on their expertise and experience. A more rigorous way of rating the issues, seeking wider input, might have been helpful though the ranking will always be dependent on the nature and priorities of the institution and its staff and students.

The group also added a stakeholder column. The problem with this was the significant difference between the stakeholders most impacted and those responsible for dealing with the issue. Which should be included in the column? The most impacted stakeholders were usually students so the column turned out not to be particularly helpful. Thus, a responsibility column was included instead, showing who is primarily responsible for dealing with the issue. While this may help institutions to assign responsibility, again, there is a level of subjectivity here and these roles will be constituted differently depending on the institution. The six types of stakeholder with primary responsibility for dealing with the issues are categorized as follows:

1. Senior management - the executive board of the institution.

2. Analytics committee - the group responsible for strategic decisions regarding learning analytics. This might be a learning and teaching committee, though some of the issues may be the responsibility of a senior champion of learning analytics rather than a more representative committee.

3. Data scientist - while the analytics committee may decide on particular issues, there is a need for data scientists or analysts to advise on issues relating to the validity of the dataset and how to interpret it.

4. Educational researcher - some issues would be best dealt with by staff with detailed knowledge of the educational aspects who are able to monitor the impact of analytics on students. This role may be carried out by teachers or tutors or those more dedicated to educational research.

5. IT - the institutional information technology department will take primary responsibility for some aspects of the analytics processes.

6. Student - while students are potentially impacted by almost every issue here, they are primarily 
responsible themselves for dealing with a few of them.

Table 1: A taxonomy of ethical, legal, and logistical issues for learning analytics.

\begin{tabular}{|c|c|c|c|c|c|}
\hline GROUP & NAME & QUESTION & TYPE & RANK & RESPONSIBILITY \\
\hline \multirow[t]{5}{*}{$\begin{array}{l}\text { Ownership \& } \\
\text { Control }\end{array}$} & $\begin{array}{l}\text { Overall } \\
\text { responsibility }\end{array}$ & $\begin{array}{l}\text { Who in the institution is responsible for the } \\
\text { appropriate and effective use of learning } \\
\text { analytics? }\end{array}$ & Logistical & 1 & $\begin{array}{l}\text { Senior } \\
\text { management }\end{array}$ \\
\hline & $\begin{array}{l}\text { Control of data for } \\
\text { analytics }\end{array}$ & $\begin{array}{l}\text { Who in the institution decides what data is } \\
\text { collected and used for analytics? }\end{array}$ & Logistical & 1 & $\begin{array}{l}\text { Senior } \\
\text { management }\end{array}$ \\
\hline & Breaking silos & $\begin{array}{l}\text { How can silos of data ownership be broken } \\
\text { in order to obtain data for analytics? }\end{array}$ & Logistical & 2 & $\begin{array}{l}\text { Analytics } \\
\text { committee }\end{array}$ \\
\hline & $\begin{array}{l}\text { Control of analytics } \\
\text { processes }\end{array}$ & $\begin{array}{l}\text { Who in the institution decides how } \\
\text { analytics are to be created and used? }\end{array}$ & Logistical & 1 & $\begin{array}{l}\text { Analytics } \\
\text { committee }\end{array}$ \\
\hline & Ownership of data & $\begin{array}{l}\text { How is ownership of data assigned across } \\
\text { stakeholders? }\end{array}$ & Legal & 1 & $\begin{array}{l}\text { Analytics } \\
\text { committee }\end{array}$ \\
\hline \multirow[t]{7}{*}{ Consent } & $\begin{array}{l}\text { When to seek } \\
\text { consent }\end{array}$ & $\begin{array}{l}\text { In which situations should students be } \\
\text { asked for consent to the collection and use } \\
\text { of their data for analytics? }\end{array}$ & $\begin{array}{l}\text { Legal/ } \\
\text { Ethical }\end{array}$ & 1 & $\begin{array}{l}\text { Analytics } \\
\text { committee }\end{array}$ \\
\hline & $\begin{array}{l}\text { Consent for } \\
\text { anonymous use }\end{array}$ & $\begin{array}{l}\text { Should students be asked for consent for } \\
\text { the collection of data that will only be used } \\
\text { in anonymized formats? }\end{array}$ & $\begin{array}{l}\text { Legal/ } \\
\text { Ethical }\end{array}$ & 3 & $\begin{array}{l}\text { Analytics } \\
\text { committee }\end{array}$ \\
\hline & $\begin{array}{l}\text { Consent for } \\
\text { outsourcing }\end{array}$ & $\begin{array}{l}\text { Do students need to give specific consent if } \\
\text { the collection and analysis of data is to be } \\
\text { outsourced to third parties? }\end{array}$ & Legal & 3 & $\begin{array}{l}\text { Analytics } \\
\text { committee }\end{array}$ \\
\hline & $\begin{array}{l}\text { Clear and } \\
\text { meaningful consent } \\
\text { processes }\end{array}$ & $\begin{array}{l}\text { How can institutions avoid opaque privacy } \\
\text { policies and ensure that students genuinely } \\
\text { understand the consent they are asked to } \\
\text { give? }\end{array}$ & $\begin{array}{l}\text { Legal/ } \\
\text { Ethical }\end{array}$ & 1 & $\begin{array}{l}\text { Analytics } \\
\text { committee }\end{array}$ \\
\hline & Right to opt out & $\begin{array}{l}\text { Do students have the right to opt out of } \\
\text { data collection and analysis of their } \\
\text { learning activities? }\end{array}$ & $\begin{array}{l}\text { Legal/ } \\
\text { Ethical }\end{array}$ & 1 & $\begin{array}{l}\text { Analytics } \\
\text { committee }\end{array}$ \\
\hline & Right to withdraw & $\begin{array}{l}\text { Do students have the right to withdraw } \\
\text { from data collection and analysis after } \\
\text { previously giving their consent? }\end{array}$ & Legal & 3 & $\begin{array}{l}\text { Analytics } \\
\text { committee }\end{array}$ \\
\hline & Right to anonymity & $\begin{array}{l}\text { Should students be allowed to disguise } \\
\text { their identity in certain circumstances? }\end{array}$ & $\begin{array}{l}\text { Ethical/ } \\
\text { Logistical }\end{array}$ & 3 & $\begin{array}{l}\text { Analytics } \\
\text { committee }\end{array}$ \\
\hline
\end{tabular}




\begin{tabular}{|c|c|c|c|c|c|}
\hline GROUP & NAME & QUESTION & TYPE & RANK & RESPONSIBILITY \\
\hline & $\begin{array}{l}\text { Adverse impact of } \\
\text { opting out on } \\
\text { individual }\end{array}$ & $\begin{array}{l}\text { If a student is allowed to opt out of data } \\
\text { collection and analysis, could this have a } \\
\text { negative impact on their academic } \\
\text { progress? }\end{array}$ & Ethical & 1 & $\begin{array}{l}\text { Analytics } \\
\text { committee }\end{array}$ \\
\hline & $\begin{array}{l}\text { Adverse impact of } \\
\text { opting out on group }\end{array}$ & $\begin{array}{l}\text { If individual students opt out, will the } \\
\text { dataset be incomplete, thus potentially } \\
\text { reducing the accuracy and effectiveness of } \\
\text { learning analytics for the group? }\end{array}$ & $\begin{array}{l}\text { Ethical/ } \\
\text { Logistical }\end{array}$ & 1 & Data scientist \\
\hline & $\begin{array}{l}\text { Lack of real choice } \\
\text { to opt out }\end{array}$ & $\begin{array}{l}\text { Do students have a genuine choice if } \\
\text { pressure is put on them by the institution } \\
\text { or if they feel their academic success may } \\
\text { be impacted by opting out? }\end{array}$ & Ethical & 3 & $\begin{array}{l}\text { Analytics } \\
\text { committee }\end{array}$ \\
\hline & $\begin{array}{l}\text { Student input to } \\
\text { analytics process }\end{array}$ & $\begin{array}{l}\text { Should students have a say in what data is } \\
\text { collected and how it is used for analytics? }\end{array}$ & Ethical & 3 & $\begin{array}{l}\text { Analytics } \\
\text { committee }\end{array}$ \\
\hline & Change of purpose & $\begin{array}{l}\text { Should institutions request consent again if } \\
\text { the data is to be used for purposes for } \\
\text { which consent was not originally given? }\end{array}$ & Legal & 2 & $\begin{array}{l}\text { Analytics } \\
\text { committee }\end{array}$ \\
\hline & Legitimate interest & $\begin{array}{l}\text { To what extent can the institution's } \\
\text { "legitimate interests" override privacy } \\
\text { controls for individuals? }\end{array}$ & Legal & 2 & $\begin{array}{l}\text { Analytics } \\
\text { committee }\end{array}$ \\
\hline & $\begin{array}{l}\text { Unknown future } \\
\text { uses of data }\end{array}$ & $\begin{array}{l}\text { How can consent be requested when } \\
\text { potential future uses of the (big) data are } \\
\text { not yet known? }\end{array}$ & Logistical & 3 & $\begin{array}{l}\text { Analytics } \\
\text { committee }\end{array}$ \\
\hline & $\begin{array}{l}\text { Consent in open } \\
\text { courses }\end{array}$ & $\begin{array}{l}\text { Are open courses (MOOCs, etc.) different } \\
\text { when it comes to obtaining consent? }\end{array}$ & $\begin{array}{l}\text { Legal/ } \\
\text { Ethical }\end{array}$ & 2 & $\begin{array}{l}\text { Analytics } \\
\text { committee }\end{array}$ \\
\hline & $\begin{array}{l}\text { Use of publicly } \\
\text { available data }\end{array}$ & $\begin{array}{l}\text { Can institutions use publicly available data } \\
\text { (e.g., tweets) without obtaining consent? }\end{array}$ & $\begin{array}{l}\text { Legal/ } \\
\text { Ethical }\end{array}$ & 3 & $\begin{array}{l}\text { Analytics } \\
\text { committee }\end{array}$ \\
\hline \multirow[t]{3}{*}{ Transparency } & $\begin{array}{l}\text { Student awareness } \\
\text { of data collection }\end{array}$ & $\begin{array}{l}\text { What should students be told about the } \\
\text { data being collected about them? }\end{array}$ & $\begin{array}{l}\text { Legal/ } \\
\text { Ethical }\end{array}$ & 1 & $\begin{array}{l}\text { Analytics } \\
\text { committee }\end{array}$ \\
\hline & $\begin{array}{l}\text { Student awareness } \\
\text { of data use }\end{array}$ & $\begin{array}{l}\text { What should students be told about the } \\
\text { uses to which their data is being put? }\end{array}$ & $\begin{array}{l}\text { Legal/ } \\
\text { Ethical }\end{array}$ & 1 & $\begin{array}{l}\text { Analytics } \\
\text { committee }\end{array}$ \\
\hline & $\begin{array}{l}\text { Student awareness } \\
\text { of algorithms and } \\
\text { metrics }\end{array}$ & $\begin{array}{l}\text { To what extent should students be given } \\
\text { details of the algorithms used for learning } \\
\text { analytics and the metrics and labels } \\
\text { created? }\end{array}$ & Ethical & 2 & $\begin{array}{l}\text { Analytics } \\
\text { committee }\end{array}$ \\
\hline
\end{tabular}




\begin{tabular}{|c|c|c|c|c|c|}
\hline GROUP & NAME & QUESTION & TYPE & RANK & RESPONSIBILITY \\
\hline & $\begin{array}{l}\text { Proprietary } \\
\text { algorithms and } \\
\text { metrics }\end{array}$ & $\begin{array}{l}\text { What should institutions do if vendors do } \\
\text { not release details of their algorithms and } \\
\text { metrics? }\end{array}$ & Logistical & 3 & $\begin{array}{l}\text { Analytics } \\
\text { committee }\end{array}$ \\
\hline & $\begin{array}{l}\text { Student awareness } \\
\text { of potential } \\
\text { consequences of } \\
\text { opting out }\end{array}$ & $\begin{array}{l}\text { What should students be told about the } \\
\text { potential consequences of opting out of } \\
\text { data collection and analysis of their } \\
\text { learning? }\end{array}$ & Ethical & 2 & $\begin{array}{l}\text { Analytics } \\
\text { committee }\end{array}$ \\
\hline & $\begin{array}{l}\text { Staff awareness of } \\
\text { data collection and } \\
\text { use }\end{array}$ & $\begin{array}{l}\text { What should teaching staff be told about } \\
\text { the data being collected about them, their } \\
\text { students, and what is being done with it? }\end{array}$ & Ethical & 1 & $\begin{array}{l}\text { Analytics } \\
\text { committee }\end{array}$ \\
\hline \multirow[t]{9}{*}{ Privacy } & Out of scope data & $\begin{array}{l}\text { Is there any data that should not be used } \\
\text { for learning analytics? }\end{array}$ & Ethical & 2 & $\begin{array}{l}\text { Analytics } \\
\text { committee }\end{array}$ \\
\hline & Tracking location & $\begin{array}{l}\text { Under what circumstances is it appropriate } \\
\text { to track the location of students? }\end{array}$ & Ethical & 2 & $\begin{array}{l}\text { Analytics } \\
\text { committee }\end{array}$ \\
\hline & Staff permissions & $\begin{array}{l}\text { To what extent should access to student } \\
\text { data be restricted within an institution? }\end{array}$ & $\begin{array}{l}\text { Ethical/ } \\
\text { Logistical }\end{array}$ & 1 & $\begin{array}{l}\text { Analytics } \\
\text { committee }\end{array}$ \\
\hline & $\begin{array}{l}\text { Unintentional } \\
\text { creation of sensitive } \\
\text { data }\end{array}$ & $\begin{array}{l}\text { How do institutions avoid creating } \\
\text { "sensitive" data, e.g., religion, ethnicity, } \\
\text { from other data? }\end{array}$ & $\begin{array}{l}\text { Legal/ } \\
\text { Logistical }\end{array}$ & 2 & Data scientist \\
\hline & $\begin{array}{l}\text { Requests from } \\
\text { external agencies }\end{array}$ & $\begin{array}{l}\text { What should institutions do when requests } \\
\text { for student data are made by external } \\
\text { agencies, e.g., educational authorities or } \\
\text { security agencies? }\end{array}$ & $\begin{array}{l}\text { Legal/ } \\
\text { Logistical }\end{array}$ & 2 & $\begin{array}{l}\text { Senior } \\
\text { management }\end{array}$ \\
\hline & $\begin{array}{l}\text { Sharing data with } \\
\text { other institutions }\end{array}$ & $\begin{array}{l}\text { Under what circumstances is it appropriate } \\
\text { to share student data with other } \\
\text { institutions? }\end{array}$ & $\begin{array}{l}\text { Legal/ } \\
\text { Ethical }\end{array}$ & 2 & $\begin{array}{l}\text { Analytics } \\
\text { committee }\end{array}$ \\
\hline & Access to employers & $\begin{array}{l}\text { Under what circumstances is it appropriate } \\
\text { to give employers access to analytics on } \\
\text { students? }\end{array}$ & Ethical & 2 & $\begin{array}{l}\text { Analytics } \\
\text { committee }\end{array}$ \\
\hline & $\begin{array}{l}\text { Enhancing trust by } \\
\text { retaining data } \\
\text { internally }\end{array}$ & $\begin{array}{l}\text { If students are told that their data will be } \\
\text { kept within the institution, will they } \\
\text { develop greater trust in and acceptance of } \\
\text { analytics? }\end{array}$ & Ethical & 3 & $\begin{array}{l}\text { Analytics } \\
\text { committee }\end{array}$ \\
\hline & $\begin{array}{l}\text { Use of metadata to } \\
\text { identify individuals }\end{array}$ & $\begin{array}{l}\text { Can students be identified from metadata } \\
\text { even if personal data has been deleted? }\end{array}$ & $\begin{array}{l}\text { Legal/ } \\
\text { Logistical }\end{array}$ & 2 & Data scientist \\
\hline
\end{tabular}


(2016). Developing a code of practice for learning analytics. Journal of Learning Analytics, 3(1), 16-42. http://dx.doi.org/10.18608/jla.2016.31.3

\begin{tabular}{|c|c|c|c|c|c|}
\hline GROUP & NAME & QUESTION & TYPE & RANK & RESPONSIBILITY \\
\hline & $\begin{array}{l}\text { Risk of re- } \\
\text { identification }\end{array}$ & $\begin{array}{l}\text { Does anonymization of data become more } \\
\text { difficult as multiple data sources are } \\
\text { aggregated, potentially leading to re- } \\
\text { identification of an individual? }\end{array}$ & $\begin{array}{l}\text { Legal/ } \\
\text { Logistical }\end{array}$ & 1 & Data scientist \\
\hline \multirow[t]{7}{*}{ Validity } & $\begin{array}{l}\text { Minimization of } \\
\text { inaccurate data }\end{array}$ & $\begin{array}{l}\text { How should an institution minimize } \\
\text { inaccuracies in the data? }\end{array}$ & Logistical & 2 & Data scientist \\
\hline & $\begin{array}{l}\text { Minimization of } \\
\text { incomplete data }\end{array}$ & $\begin{array}{l}\text { How should an institution minimize } \\
\text { incompleteness of the dataset? }\end{array}$ & Logistical & 2 & Data scientist \\
\hline & $\begin{array}{l}\text { Optimum range of } \\
\text { data sources }\end{array}$ & $\begin{array}{l}\text { How many and which data sources are } \\
\text { necessary to ensure accuracy in the } \\
\text { analytics? }\end{array}$ & Logistical & 2 & Data scientist \\
\hline & $\begin{array}{l}\text { Validation of } \\
\text { algorithms and } \\
\text { metrics }\end{array}$ & $\begin{array}{l}\text { How should an institution validate its } \\
\text { algorithms and metrics? }\end{array}$ & $\begin{array}{l}\text { Ethical/ } \\
\text { Logistical }\end{array}$ & 1 & Data scientist \\
\hline & $\begin{array}{l}\text { Spurious } \\
\text { correlations }\end{array}$ & $\begin{array}{l}\text { How can institutions avoid drawing } \\
\text { misleading conclusions from spurious } \\
\text { correlations? }\end{array}$ & $\begin{array}{l}\text { Ethical/ } \\
\text { Logistical }\end{array}$ & 2 & Data scientist \\
\hline & $\begin{array}{l}\text { Evolving nature of } \\
\text { students }\end{array}$ & $\begin{array}{l}\text { How accurate can analytics be when } \\
\text { students' identities and actions evolve over } \\
\text { time? }\end{array}$ & Logistical & 3 & $\begin{array}{l}\text { Educational } \\
\text { researcher }\end{array}$ \\
\hline & $\begin{array}{l}\text { Authentication of } \\
\text { public data sources }\end{array}$ & $\begin{array}{l}\text { How can institutions ensure that student } \\
\text { data taken from public sites is } \\
\text { authenticated to their students? }\end{array}$ & Logistical & 3 & IT \\
\hline \multirow[t]{5}{*}{ Access } & $\begin{array}{l}\text { Student access to } \\
\text { their data }\end{array}$ & $\begin{array}{l}\text { To what extent should students be able to } \\
\text { access the data held about them? }\end{array}$ & Legal & 1 & $\begin{array}{l}\text { Analytics } \\
\text { committee }\end{array}$ \\
\hline & $\begin{array}{l}\text { Student access to } \\
\text { their analytics }\end{array}$ & $\begin{array}{l}\text { To what extent should students be able to } \\
\text { access the analytics performed on their } \\
\text { data? }\end{array}$ & $\begin{array}{l}\text { Legal/ } \\
\text { Ethical }\end{array}$ & 1 & $\begin{array}{l}\text { Analytics } \\
\text { committee }\end{array}$ \\
\hline & Data formats & $\begin{array}{l}\text { In what formats should students be able to } \\
\text { access their data? }\end{array}$ & Logistical & 2 & $\begin{array}{l}\text { Analytics } \\
\text { committee }\end{array}$ \\
\hline & Metrics and labels & $\begin{array}{l}\text { Should students see the metrics and labels } \\
\text { attached to them? }\end{array}$ & Ethical & 2 & $\begin{array}{l}\text { Analytics } \\
\text { committee }\end{array}$ \\
\hline & $\begin{array}{l}\text { Right to correct } \\
\text { inaccurate data }\end{array}$ & $\begin{array}{l}\text { What data should students be allowed to } \\
\text { correct about themselves? }\end{array}$ & Legal & 1 & $\begin{array}{l}\text { Analytics } \\
\text { committee }\end{array}$ \\
\hline
\end{tabular}


(2016). Developing a code of practice for learning analytics. Journal of Learning Analytics, 3(1), 16-42. http://dx.doi.org/10.18608/jla.2016.31.3

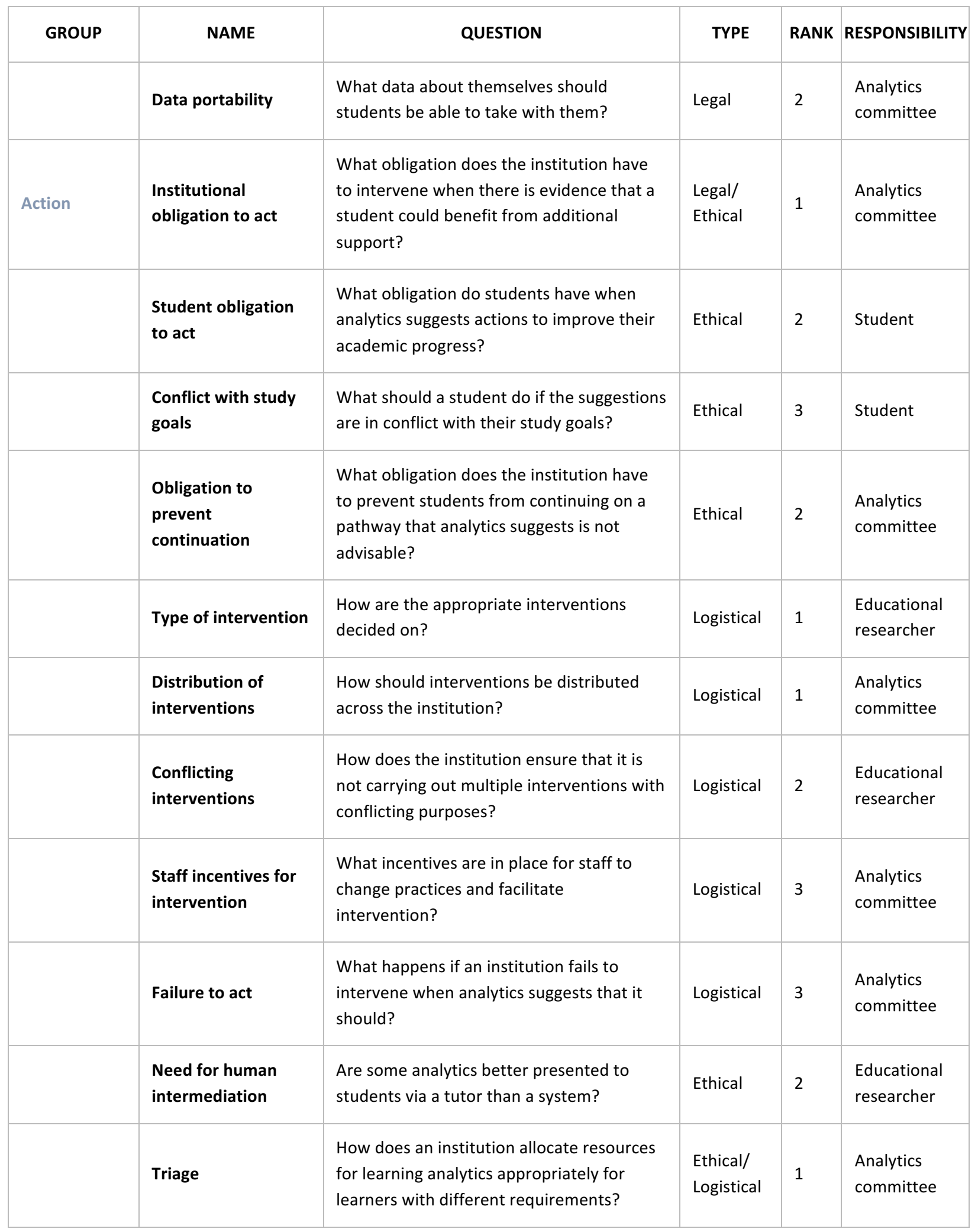


(2016). Developing a code of practice for learning analytics. Journal of Learning Analytics, 3(1), 16-42. http://dx.doi.org/10.18608/jla.2016.31.3

\begin{tabular}{|c|c|c|c|c|c|}
\hline GROUP & NAME & QUESTION & TYPE & RANK & RESPONSIBILITY \\
\hline & Triage transparency & $\begin{array}{l}\text { How transparent should an institution be in } \\
\text { how it allocates resources to different } \\
\text { groups? }\end{array}$ & Ethical & 3 & $\begin{array}{l}\text { Analytics } \\
\text { committee }\end{array}$ \\
\hline & Opportunity cost & $\begin{array}{l}\text { How is spending on learning analytics } \\
\text { justified in relation to other funding } \\
\text { requirements? }\end{array}$ & Logistical & 2 & $\begin{array}{l}\text { Senior } \\
\text { management }\end{array}$ \\
\hline & $\begin{array}{l}\text { Favouring one } \\
\text { group over another }\end{array}$ & $\begin{array}{l}\text { Could the intervention strategies unfairly } \\
\text { favour one group over another? }\end{array}$ & $\begin{array}{l}\text { Ethical/ } \\
\text { Logistical }\end{array}$ & 2 & $\begin{array}{l}\text { Educational } \\
\text { researcher }\end{array}$ \\
\hline & $\begin{array}{l}\text { Consequences of } \\
\text { false information }\end{array}$ & $\begin{array}{l}\text { What should institutions do if a student } \\
\text { gives false information, e.g., to obtain } \\
\text { additional support? }\end{array}$ & Logistical & 3 & $\begin{array}{l}\text { Analytics } \\
\text { committee }\end{array}$ \\
\hline & Audit trails & $\begin{array}{l}\text { Should institutions record audit trails of all } \\
\text { predictions and interventions? }\end{array}$ & Logistical & 2 & $\begin{array}{l}\text { Analytics } \\
\text { committee }\end{array}$ \\
\hline & Unexpected findings & $\begin{array}{l}\text { How should institutions deal with } \\
\text { unexpected findings arising in the data? }\end{array}$ & Logistical & 3 & $\begin{array}{l}\text { Analytics } \\
\text { committee }\end{array}$ \\
\hline \multirow[t]{6}{*}{$\begin{array}{l}\text { Adverse } \\
\text { impact }\end{array}$} & Labelling bias & $\begin{array}{l}\text { Does labelling or profiling students bias } \\
\text { institutional perceptions and behaviours } \\
\text { towards them? }\end{array}$ & Ethical & 1 & $\begin{array}{l}\text { Educational } \\
\text { researcher }\end{array}$ \\
\hline & Oversimplification & $\begin{array}{l}\text { How can institutions avoid overly simplistic } \\
\text { metrics and decision making that ignore } \\
\text { personal circumstances? }\end{array}$ & Ethical & 1 & $\begin{array}{l}\text { Educational } \\
\text { researcher }\end{array}$ \\
\hline & $\begin{array}{l}\text { Undermining of } \\
\text { autonomy }\end{array}$ & $\begin{array}{l}\text { Is student autonomy in decision making } \\
\text { undermined by predictive analytics? }\end{array}$ & Ethical & 2 & $\begin{array}{l}\text { Educational } \\
\text { researcher }\end{array}$ \\
\hline & Gaming the system & $\begin{array}{l}\text { If students know that data is being } \\
\text { collected about them, will they alter their } \\
\text { behaviour to present themselves more } \\
\text { positively, thus distracting them and } \\
\text { skewing the analytics? }\end{array}$ & Ethical & 2 & $\begin{array}{l}\text { Educational } \\
\text { researcher }\end{array}$ \\
\hline & Abusing the system & $\begin{array}{l}\text { If students understand the algorithms, will } \\
\text { they manipulate the system to obtain } \\
\text { additional support? }\end{array}$ & Ethical & 3 & $\begin{array}{l}\text { Educational } \\
\text { researcher }\end{array}$ \\
\hline & $\begin{array}{l}\text { Adverse behavioural } \\
\text { impact }\end{array}$ & $\begin{array}{l}\text { If students are presented with data about } \\
\text { their performance, could this have a } \\
\text { negative impact e.g., increased likelihood of } \\
\text { dropout? }\end{array}$ & Ethical & 1 & $\begin{array}{l}\text { Educational } \\
\text { researcher }\end{array}$ \\
\hline
\end{tabular}


(2016). Developing a code of practice for learning analytics. Journal of Learning Analytics, 3(1), 16-42. http://dx.doi.org/10.18608/jla.2016.31.3

\begin{tabular}{|c|c|c|c|c|c|}
\hline GROUP & NAME & QUESTION & TYPE & RANK & RESPONSIBILITY \\
\hline & $\begin{array}{l}\text { Reinforcement of } \\
\text { discrimination }\end{array}$ & $\begin{array}{l}\text { Could analytics reinforce discriminatory } \\
\text { attitudes and actions by profiling students } \\
\text { based on their race or gender? }\end{array}$ & Ethical & 1 & $\begin{array}{l}\text { Educational } \\
\text { researcher }\end{array}$ \\
\hline & $\begin{array}{l}\text { Reinforcement of } \\
\text { social power } \\
\text { differentials }\end{array}$ & $\begin{array}{l}\text { Could analytics reinforce social power } \\
\text { differentials and students' status in relation } \\
\text { to each other? }\end{array}$ & Ethical & 2 & $\begin{array}{l}\text { Educational } \\
\text { researcher }\end{array}$ \\
\hline & Infantilization & $\begin{array}{l}\text { Could analytics "infantilize" students by } \\
\text { spoon-feeding them with automated } \\
\text { suggestions, making the learning process } \\
\text { less demanding? }\end{array}$ & Ethical & 3 & $\begin{array}{l}\text { Educational } \\
\text { researcher }\end{array}$ \\
\hline & Echo chambers & $\begin{array}{l}\text { Could analytics create "echo chambers" } \\
\text { where intelligent software reinforces our } \\
\text { own attitudes and beliefs? }\end{array}$ & Ethical & 3 & $\begin{array}{l}\text { Educational } \\
\text { researcher }\end{array}$ \\
\hline & Non-participation & $\begin{array}{l}\text { Will the knowledge that they are being } \\
\text { monitored lead to non-participation by } \\
\text { students? }\end{array}$ & Ethical & 2 & $\begin{array}{l}\text { Educational } \\
\text { researcher }\end{array}$ \\
\hline \multirow[t]{6}{*}{ Stewardship } & Data minimization & $\begin{array}{l}\text { Is all the data held on an individual } \\
\text { necessary in order to carry out the } \\
\text { analytics? }\end{array}$ & Legal & 1 & Data scientist \\
\hline & $\begin{array}{l}\text { Data processing } \\
\text { location }\end{array}$ & $\begin{array}{l}\text { Is the data being processed in a country } \\
\text { permitted by the local data protection } \\
\text { laws? }\end{array}$ & Legal & 1 & IT \\
\hline & $\begin{array}{l}\text { Right to be } \\
\text { forgotten }\end{array}$ & $\begin{array}{l}\text { Can all data regarding an individual (except } \\
\text { that necessary for statutory purposes) be } \\
\text { deleted? }\end{array}$ & Legal & 1 & IT \\
\hline & $\begin{array}{l}\text { Unnecessary data } \\
\text { retention }\end{array}$ & How long should data be retained? & Legal & 1 & $\begin{array}{l}\text { Analytics } \\
\text { committee }\end{array}$ \\
\hline & $\begin{array}{l}\text { Unhelpful data } \\
\text { deletion }\end{array}$ & $\begin{array}{l}\text { If data is deleted, does this restrict the } \\
\text { institution's analytics capabilities, e.g., } \\
\text { refining its models and tracking } \\
\text { performance over multiple cohorts? }\end{array}$ & Logistical & 2 & Data scientist \\
\hline & $\begin{array}{l}\text { Incomplete } \\
\text { knowledge of data } \\
\text { sources }\end{array}$ & $\begin{array}{l}\text { Can an institution be sure that it knows } \\
\text { where all personal data is held? }\end{array}$ & $\begin{array}{l}\text { Legal/ } \\
\text { Logistical }\end{array}$ & 1 & IT \\
\hline
\end{tabular}




\begin{tabular}{|c|c|c|c|c|c|}
\hline GROUP & NAME & QUESTION & TYPE & RANK & RESPONSIBILITY \\
\hline & $\begin{array}{l}\text { Inappropriate data } \\
\text { sharing }\end{array}$ & $\begin{array}{l}\text { How can data sharing be prevented with } \\
\text { parties who have no legitimate interest in } \\
\text { seeing it or who may use it inappropriately? }\end{array}$ & Legal & 1 & $\mathrm{IT}$ \\
\hline
\end{tabular}

\section{DRAFTING THE CODE OF PRACTICE}

After the taxonomy was made available on the project blog, and with further in-depth feedback from members of the advisory group, it proved relatively easy to draft the Code of Practice using the taxonomy as its basis. All those issues with a priority level of 1 or 2 were incorporated into the Code. Given the brief nature of the summary document, guidance in how to deal with the issues is by necessity at a basic level, but, as stated earlier, more in-depth advice and case studies will be included in an accompanying website, which is under development.

\section{$5.1 \quad$ Introduction}

The Code is grouped into eight areas, based on the categories in the taxonomy, and preceded by an introduction that emphasises two of the key themes of the Code, i.e., that learning analytics should be for the benefit of students, and that it should be carried out transparently. It also notes that many of the processes of learning analytics, particularly in the area of data protection, should be covered by existing institutional policies.

Learning analytics uses data about students and their activities to help institutions understand and improve educational processes, and provide better support to learners.

It should be for the benefit of students, whether assisting them individually or using aggregated and anonymized data to help other students or to improve the educational experience more generally. It is distinct from assessment, and should be used for formative rather than summative purposes.

The effective use of learning analytics will initially involve the deployment of new systems, and changes to institutional policies and processes. New data may be collected on individuals and their learning activities. Analytics will be performed on this data, and interventions may take place as a result. This presents opportunities for positive engagements and impacts on learning, as well as misunderstandings, misuse of data and adverse impacts on students.

Complete transparency and clear institutional policies are therefore essential regarding the purposes of learning analytics, the data collected, the processes involved, and how they will be used to enhance the educational experience.

This code of practice aims to set out the responsibilities of educational institutions to ensure that learning analytics is carried out responsibly, appropriately and effectively, addressing the key legal, ethical and logistical issues which are likely to arise.

Educational institutions in the UK already have information management practices and procedures 
in place and have extensive experience of handling sensitive and personal data in accordance with the Data Protection Act (DPA) 1998.

By transferring and adapting this expertise to regulate the processing of data for learning analytics, institutions should establish the practices and procedures necessary to process the data of individuals lawfully and fairly.

\subsection{Responsibility}

The next section aims to make it clear that responsibility in the institution for the various processes of learning analytics needs to be allocated appropriately and that students and other stakeholders should be consulted.

Institutions must decide who has overall responsibility for the legal, ethical, and effective use of learning analytics. They should allocate specific responsibility within the institution for:

- The collection of data to be used for learning analytics

- The anonymisation of the data where appropriate

- The analytics processes to be performed on the data, and their purposes

- The interventions to be carried out

- The retention and stewardship of data used for and generated by learning analytics

Student representatives and key staff groups at institutions should be consulted around the objectives, design, development, roll-out and monitoring of learning analytics.

\subsection{Transparency and Consent}

The next part of the Code is about being open about all aspects of the use of learning analytics, and ensuring that students provide meaningful, informed consent. The area of requesting consent is not straightforward, as the UK Data Protection Act (1998), derived from the European Data Protection Directive (European Commission, 1995), does not always require obtaining consent, for example, when data collection is necessary for the "legitimate interests" of an organization. Meanwhile a balance must be struck between obtaining meaningful consent for learning analytics but not bombarding students with continual requests for permission on every aspect of data collection and use. The consensus of the advisory group and various experts consulted was that obtaining consent for interventions to be taken based on a student's data is key. Allowing students to opt-out of data collection may, in some cases, make the carrying out of normal educational processes impossible; for example, virtual learning environments collect data on student activity by default and cannot function without doing so.

Institutions will define the objectives for the use of learning analytics, what data is necessary to achieve these objectives, and what is out of scope. The data sources, the purposes of the analytics, the metrics used, who has access to the analytics, the boundaries around usage, and how to interpret the data will be explained clearly to staff and students.

Institutions should also clearly describe the processes involved in producing the analytics to students and staff or make the algorithms transparent to them. 
Students will normally be asked for their consent for personal interventions to be taken based on the learning analytics. This may take place during the enrolment process or subsequently. There may however be legal, safeguarding or other circumstances where students are not permitted to opt out of such interventions. If so these must be clearly stated and justified.

New learning analytics projects may not be covered by the institution's existing arrangements. Collection and use of data for these may require further measures, such as privacy impact assessments and obtaining additional consent.

Options for granting consent must be clear and meaningful, and any potential adverse consequences of opting out must be explained. Students should be able easily to amend their decisions subsequently.

\subsection{Privacy}

The Code here emphasizes that access to student data should be carefully controlled and data protection legislation complied with. There is doubt as to whether in the age of Big Data it is ever possible to anonymize an individual's data such that they cannot be re-identified at some stage (e.g., Bollier, 2010), but institutions should make every effort to do so if an individual's data is to be used anonymously. Meanwhile, any sharing of data outside the institution should be made clear to students and staff. It was also felt to be important to state that institutions may have legal obligations to override privacy restrictions, for example, when analytics identify a student who appears to be at risk of suicide.

Access to student data and analytics should be restricted to those identified by the institution as having a legitimate need to view them.

Where data is to be used anonymously particular care will be taken by institutions to avoid:

- Identification of individuals from metadata

- Re-identification of individuals by aggregating multiple data sources

The use of "sensitive data" (as defined by the DPA), such as religious affiliation and ethnicity, for the purposes of learning analytics requires additional safeguards. Circumstances where data and analytics could be shared externally - e.g., requests from educational authorities, security agencies or employers - will be made explicit to staff and students, and may require additional consent.

Institutions should ensure that student data is protected when contracting third parties to store data or carry out learning analytics on it.

Institutions may have a legal obligation to intervene, and hence override some privacy restrictions, where data or analytics reveal that a student is at risk. Such circumstances should be clearly specified.

\section{$5.5 \quad$ Validity}

Predictive analytics are worthless unless the data is accurate and the algorithms are valid. For this reason, 
it was thought important ethically, and potentially legally too, that expertise existed in the institution to ensure that the analytics processes, which could affect students' careers and lives, were understood. Meanwhile, it is stressed that even if the analytics is valid it needs to be seen in the wider context of an individual's experience.

It is vital that institutions monitor the quality, robustness and validity of their data and analytics processes in order to develop and maintain confidence in learning analytics and ensure it is used to the benefit of students. Institutions should ensure that:

- Inaccuracies in the data are understood and minimised

- The implications of incomplete datasets are understood

- The optimum range of data sources is selected

- Spurious correlations are avoided

All algorithms and metrics used for predictive analytics or interventions should be understood, validated, reviewed and improved by appropriately qualified staff.

Data and analytics may be valid but should also be useful and appropriate; learning analytics should be seen in its wider context and combined with other data and approaches as appropriate.

\subsection{Access}

Few institutions are yet in a position to provide a student with a copy of all the data held about them (including the analytics performed on their data, which, also, is itself data). However, individuals in Europe do have a legal right to request this information, and institutions must work to facilitate this. That does not mean providing students automatically with all the metrics on their academic process, but it does mean doing so if the student requests such information.

Students should be able to access all learning analytics performed on their data in meaningful, accessible formats, and to obtain copies of this data in a portable digital format. Students have a legal right under the DPA to be able to correct inaccurate personal data held about themselves. [...] They should normally also be able to view the metrics and labels attached to them. If an institution considers that the analytics may have a harmful impact on the student's academic progress or wellbeing it may withhold the analytics from the student, subject to clearly defined and explained policies. However, the student must be shown the data about them if they ask to see it.

\subsection{Enabling Positive Interventions}

As with the other sections, this one reflects concerns expressed in the literature. The frequently quoted "obligation to act" for both institutions and students (e.g., Campbell, DeBlois, \& Oblinger, 2007; Kay, Korn, \& Oppenheim, 2012; Willis \& Pistilli, 2014) is covered, as are the main potential pitfalls of intervening directly with students based on analytics.

Institutions should specify under which circumstances they believe they should intervene when analytics suggests that a student could benefit from additional support. This may include advising 
students that they should not continue on a particular pathway. Students may also have obligations to act on the analytics presented to them - if so these should be clearly set out and communicated to the students.

The type and nature of interventions, and who is responsible for carrying them out, should be clearly specified. Some may require human rather than digital intermediation. Predictions and interventions will normally be recorded, and auditable, and their appropriateness and effectiveness reviewed.

The impact of interventions on staff roles, training requirements and workload will be considered and requires support from senior management. Institutions will also be clear about the priority given to learning analytics in relation to other requirements.

Institutions will decide how to allocate resources for learning analytics appropriately for learners with different requirements and ensure that diverse groups and individuals are treated equitably.

\subsection{Minimizing Adverse Impacts}

Some of the reservations frequently expressed in discussions and in the literature are covered here. For example, analytics should not treat an individual as a number, and institutions should be careful not to prejudice students' chances by categorizing them (Campbell, DeBlois, \& Oblinger, 2007; Greller \& Drachsler, 2012). There are also potential detrimental effects when student progress is being analyzed, so these need to be understood and minimized. MacCarthy (2014) points out that the algorithms used for learning analytics may reinforce discriminatory attitudes, while Swenson (2014) suggests that interventions might favour one group over another (for example, campus based over distance students).

Institutions recognize that analytics can never give a complete picture of an individual's learning and may sometimes ignore personal circumstances.

Institutions will take steps to ensure that trends, norms, categorization or any labelling of students do not bias staff, student or institutional perceptions and behaviours towards them, reinforce discriminatory attitudes or increase social power differentials.

Analytics systems and interventions will be carefully designed and regularly reviewed to ensure that:

- Students maintain appropriate levels of autonomy in decision making relating to their learning, using learning analytics where appropriate to help inform their decisions

- Opportunities for "gaming the system" or any benefit to the student from doing so are minimised

- Knowledge that their activity is being monitored does not lead to non-participation by students or other negative impacts on their academic progress or wellbeing

- Adverse impacts as a result of giving students and staff information about the students' performance or likelihood of success are minimised

- Staff have a working understanding of legal, ethical and unethical practice. 


\section{$5.9 \quad$ Stewardship of Data}

Finally, a section was included to remind institutions of their responsibilities to look after student data carefully. European legislation does cause a potential restriction here on the use of Big Data for learning analytics: the uses to which the data can be put are often not known in advance, so minimizing the data that is kept, and destroying it after a period, might restrict institutions' abilities to obtain valuable insight on student behaviour. However, institutions do need to comply with the legislation and should arguably obtain additional consent from students if they wish to retain their data for longer periods.

Data for learning analytics will comply with existing institutional data policies and the DPA, and will in particular be:

- $\quad$ Kept to the minimum necessary to deliver the purposes of the analytics reliably

- Processed in the European Economic Area or, if elsewhere, only in accordance with the DPA

- $\quad$ Retained only for appropriate and clearly defined periods

On request by students any personal data used for or generated by learning analytics should be destroyed or anonymised, with the exception of certain, clearly specified data fields required for educational or statutory purposes such as grades.

\section{A MODEL FOR THE DEVELOPMENT OF A CODE OF PRACTICE}

Others have wrestled with how best to develop a code of practice. The Institute for Business Ethics (IBE, 2015) and the International Federation of Accountants (PABC, 2007) each suggest a number of broadly similar steps to be taken in the development of a code of ethics or a code of conduct. While relevant, these relate to the development of a code for a single institution rather than an educational sector or profession. Table 2 summarizes these steps and shows how they have been implemented in the development of Jisc's sector-wide Code of Practice.

Table 2: Actions taken to develop the Code of Practice.

\begin{tabular}{l|l}
$\begin{array}{l}\text { Proposed step } \\
\begin{array}{l}\text { Gain the commitment of } \\
\text { senior management }\end{array}\end{array}$ & $\begin{array}{l}\text { Action taken to develop the Code of Practice } \\
\text { the prioritization by the further and higher education community in the } \\
\text { UK that the ethical and legal issues of learning analytics needed to be } \\
\text { addressed as a matter of urgency. }\end{array}$ \\
$\begin{array}{l}\text { Find a champion and set up } \\
\text { a committee to oversee } \\
\text { development and } \\
\text { implementation }\end{array}$ & $\begin{array}{l}\text { A consultant was employed to lead the development of the Code, and an } \\
\text { advisory group with expert representation from the sector was set up. }\end{array}$ \\
Identify stakeholders, what & The advisory group was appointed, consisting of experts from
\end{tabular}




\section{is important to them, and who should be involved in code development and implementation \\ Agree on the purpose of the code and how it will be used \\ Review existing external and multi-sector conduct guidelines \\ Draft the content, perhaps by a working group comprising representatives from various functions in an organization}

Test, pilot, and approve the code

Publish and publicize it

Review the code and its impact, taking into account changing requirements and stakeholder concerns

Provide training and communication as a means to embed the code

Connect the code to the organization's (a) performance management policies and systems, and (b) internal controls universities and colleges, and a student representative from the National Union of Students.

The advisory group decided on the approach to producing the Code, the areas to be covered, ways to gain further validation from the community, dissemination, and adoption.

The literature review identified key aspects of guidelines and codes in related areas, as well as summarizing the main ethical and legal issues of learning analytics arising in the literature.

The taxonomy of issues was developed with assistance from Apereo and Lace. This provided the basis for the Code drafted by the consultant and refined by the advisory group.

The advisory group approved the Code; testing and piloting in institutions is ongoing.

The Code was launched at a prominent event, published on the Jisc website, and disseminated heavily.

This will happen once the Code has been adopted by a number of institutions. Some are already reporting the influence it is having on the development of internal learning analytics policies.

Conference presentations and workshops are encouraging the Code's adoption by institutions. Support materials, including a series of podcasts, have been developed for the accompanying website.

This crucial step is beginning to happen as institutions develop their own codes that build on Jisc's documents and link to other internal policies. 
The activities involved in the production of the Code of Practice for Learning Analytics potentially provide the basis for a generalizable model for developing codes of practices in other professions or areas of education. An outline of the model is provided in the diagram shown in Figure 2.

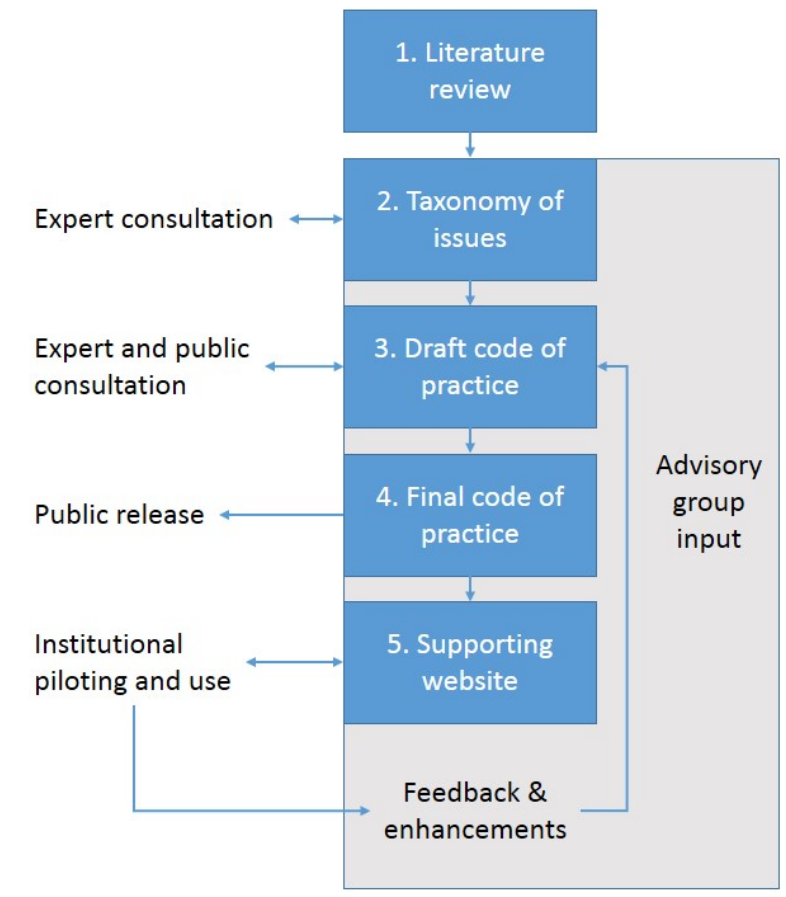

Figure 2: A model for the development of a code of practice.

Five products are developed during this process. First, a literature review (1) captures the main ethical, legal, and logistical concerns being raised. At this point, an advisory group is recruited, bringing in expertize from the sector and representing key stakeholder groups. The advisory group can continue until the code is published or could be retained on an ongoing basis to ensure that the code and supporting website remain relevant. It could even be set up earlier to guide the production of the literature review, if necessary.

The literature review informs a taxonomy of issues (2), which is refined through expert consultation in the sector. The draft code of practice (3) is then produced and sent to experts and stakeholder groups as part of a public consultation for a fixed period. Feedback is incorporated into a final code of practice (4) document, which is released publicly both online and through associated events if appropriate. A supporting website (5) is populated with further guidance and case studies. As institutions pilot the code of practice, they provide feedback and suggested enhancements that can be fed into a new draft for an updated version of the code at a later stage.

The model requires a number of factors to be in place in order for it to be effective; some of these may be problematic in other sectors or industries:

1. An established literature base outlining the issues of concern 
2. Organizations wishing to contribute, and to be part of a representative advisory group, regarded as credible by the sector

3. Communication mechanisms enabling adequate consultation with the sector

4. Institutions willing to pilot the code of practice and provide feedback for its enhancement

5. An ongoing commitment to reviewing and updating the document in order to ensure it remains relevant

In addition, organizing the development of a code of practice will require financial input and time commitment from representatives. It is hoped that the iterative aspect of the model outlined above will be tested by the development of a version 2.0 of the Code of Practice for Learning Analytics once institutions have provided further feedback on its usefulness and limitations. While this model may not be appropriate for the development of other codes of practice in its entirety, the various products and stages have helped to ensure that the Code was rigorously researched, widely consulted on, and well disseminated. These factors should assist with its adoption in institutions, or at least with raising consciousness about the issues that need to be tackled at the organizational level.

\section{$7 \quad$ CONCLUSION}

The Code of Practice for Learning Analytics produced by Jisc covers the main concerns for students and institutions that commonly arise in the literature and in discussions. The rigorous and consensual approach to developing the document through its various stages aims to help ensure its adoption. The draft Code was sent to a wide range of educational organizations and received much detailed feedback, most of which was incorporated. Much of this attempted to tidy up ambiguities in the wording, particularly where it related to legal issues. The final version was released at an event in Salford in June 2015 (Sclater, 2015d) and received much interest online.

The primary purpose of the Code is to help institutions deal with ethical objections and legal uncertainties, and to facilitate the further development of the field of learning analytics. The document's brevity and the clear language and formatting employed aim to encourage people to read it and to grasp quickly the most salient issues. Adoption of the Code by institutions and their employees and students, however, is by no means guaranteed, and agreeing with the document is of course much easier than applying it to all necessary areas of institutional business. Its main value may be in raising the issues and providing a checklist for institutions to consider; ultimately, it is their responsibility to apply its principles to their own activities, to embed the concepts in their policies as appropriate and to ensure that these are implemented effectively.

Promising signs of its influence are already emerging. The National Union of Students has produced a guide for students' unions that builds on the Code of Practice and links to it (NUS, 2015). The UK's Higher Education Academy outlines the eight areas of the Code in its Learning Analytics Toolkit (HEA, 2015). Meanwhile the University of Edinburgh links to the Code in its emerging "Guidance on learning analytics and data protection" and suggests that it is "a good starting point for staff in identifying relevant issues 
and how to address them, to ensure that learning analytics is carried out responsibly and effectively" (University of Edinburgh, 2015).

The Code was developed in the UK context and refers to the Data Protection Act 1998. However, most of it is relevant to institutions wishing to carry out learning analytics anywhere, particularly in other European countries with similar data protection legislation. The development and release of the document has been of considerable interest elsewhere, notably in the USA, Australia, and the Netherlands. In the latter, a "Guide to Learning Analytics under the Personal Data Protection Act," building on Jisc's work, has been published (SURF, 2015).

While its reception has been overwhelmingly positive, one USA-based vendor, commenting on a publicly available draft of the Code, felt that it put unnecessary restrictions on institutions and would thus hold back the development of learning analytics. This is precisely the opposite of what is intended. The lack of a code of practice for learning analytics has been paralyzing many institutions, preventing them from moving forward and hampering the development of a critical set of technologies and processes with potentially significant impacts on the lives of individual learners. Clarifying the issues and proposing transparent, ethical solutions that comply with strict data protection legislation should help to break the deadlock and enable the further development and rollout of learning analytics. Interest has been expressed in adapting the document for use in the Netherlands and France. Meanwhile, several UK universities have already indicated that they will use the Code as the basis for their institutional policies on learning analytics.

The supporting website is currently being developed and will include case studies and more detailed and practical guidance for institutions on how to deal with the problems they encounter. As Jisc rolls out its basic learning analytics solution to UK institutions (Sclater, 2015c), experience of local implementations will be captured and fed into the guidance, together with examples of how institutions elsewhere in the world have dealt with ethical and legal barriers.

\section{REFERENCES}

Berg, A. (2013, September 13). Towards a uniform code of ethics and practices for learning analytics. [Web log post]. Retrieved from http://ict-innovatie.uva.nl/2013/09/13/towards-a-uniform-code-ofethics-and-practices-for-learning-analytics/

Bollier, D. (2010). The promise and peril of big data. Washington, DC: The Aspen Institute. Retrieved from http://www.aspeninstitute.org/sites/default/files/content/docs/pubs/The_Promise_and_Peril_ of_Big_Data.pdf

Campbell, J. P., DeBlois, P. B., \& Oblinger, D. G. (2007). Academic analytics: A new tool for a new era. EDUCAUSE Review, 42(4), 40-57. Retrieved from http://www.educause.edu/ero/article/academic-analytics-new-tool-new-era

Council Directive 95/46/EC on the protection of individuals with regard to the processing of personal data and on the free movement of such data [1995] OJ L 281/31

Ferguson, R. (2012). Learning analytics: Drivers, developments and challenges. International Journal of 
Technology Enhanced Learning, 4(5-6), 304. http://oro.open.ac.uk/36374/

Greller, W., \& Drachsler, H. (2012). Translating learning into numbers: A generic framework for learning analytics. Educational Technology \& Society, 15(3), 42-57.

HEA (Higher Education Academy). (2015). "Learning analytics." HEA Starter Tools. Retrieved from https://www.heacademy.ac.uk/enhancement/starter-tools/learning-analytics

IBE (Institute for Business Ethics). (2015). Nine steps for preparing a new code. Retrieved from http://www.ibe.org.uk/nine-steps-for-preparing-a-new-code/103/52

ICO (Information Commissioner's Office). (2010, July). Personal information online code of practice. Retrieved from https://ico.org.uk//for-organisations/guide-to-data-protection/

Kay, D., Korn, N., \& Oppenheim, C. (2012, November). Legal, risk and ethical aspects of analytics in higher education, JISC CETIS Analytics Series, 1(6). Retrieved from http://publications.cetis.ac.uk/2012/500

K.N.C. (2014, April 30). Withered inBloom. The Economist. Retrieved from http://www.economist.com/node/21601484/print

King, J. H., \& Richards, N. M. (2014, March 28). What's up with big data ethics? Forbes. http://www.forbes.com/sites/oreillymedia/2014/03/28/whats-up-with-big-data-ethics/

MacCarthy, M. (2014). Student privacy: Harm and context. International Review of Information Ethics, 21, 11-24. Retrieved from http://www.i-r-i-e.net/inhalt/021/IRIE-021-MacCarthy.pdf

NUS (National Union of Students). (2015, August). Learning analytics: A guide for students' unions. Retrieved from http://www.nusconnect.org.uk/resources/learning-analytics-a-guide-forstudents-unions

Open University (2014). Policy on ethical use of student data for learning analytics. Retrieved from http://www.open.ac.uk/students/charter/essential-documents/ethical-use-student-datalearning-analytics-policy

Professional Accountants in Business Committee. (2007). Defining and developing an effective code of conduct for organizations. International Federation of Accountants. Retrieved from http://www.ifa.org.uk/files/PAlB code-of-conduct.pdf

Pardo, A., \& Siemens, G. (2014). Ethical and privacy principles for learning analytics. British Journal of Educational Technology, 45, 438-450. http://dx.doi.org/10.1111/bjet.12152

President's Council of Advisors on Science and Technology. (2014). Big data and privacy: A technological perspective. Report to the President. Retrieved from http://www.whitehouse.gov/sites/default/files/microsites/ostp/PCAST/pcast_big_data_and_pri vacy_-_may_2014.pdf

RESPECT Project. (2004). Code of practice for socio-economic research. Institute for Employment Studies. Retrieved from http://www.respectproject.org/code/respect_code.pdf

Shroepfer, M. (2014, October 2). Research at Facebook. Facebook Newsroom. Retrieved from http://newsroom.fb.com/news/2014/10/research-at-facebook/

Siemens, G. (2012). Learning analytics: Envisioning a research discipline and a domain of practice. Proceedings of the $2^{\text {nd }}$ International Conference on Learning Analytics and Knowledge, 4-8. http://dx.doi.org/10.1145/2330601.2330605

Sclater, N. (2014a, September 16). Taking learning analytics to the next stage. Effective Learning Analytics. Jisc. [Web log post]. Retrieved from http://analytics.jiscinvolve.org/wp/2014/09/16/takinglearning-analytics-to-the-next-stage/

Sclater, N. (2014b). Code of practice for learning analytics: A literature review of the ethical and legal issues. Jisc. Retrieved from http://repository.jisc.ac.uk/5661/1/Learning_Analytics_A_Literature_Review.pdf 
Sclater, N. (2014c, October 29). Notes from Utrecht workshop on ethics and privacy issues in the application of learning analytics. Effective Learning Analytics. Jisc. [Web log post]. Retrieved from http://analytics.jiscinvolve.org/wp/2014/10/29/notes-from-utrecht-workshop-on-ethics-andprivacy-issues-in-the-application-of-learning-analytics/

Sclater, N. (2014d, November). Learning analytics: The current state of play in UK higher and further education. Jisc. Retrieved from http://repository.jisc.ac.uk/5657/1/Learning_analytics_report.pdf

Sclater, N. (2015a, January 30). Developing the code of practice. Effective Learning Analytics. Jisc. [Web log post]. Retrieved from http://analytics.jiscinvolve.org/wp/2015/01/30/developing-the-codeof-practice/

Sclater, N. (2015b, March 3). A taxonomy of the ethical and legal issues of learning analytics v0.1. Effective Learning Analytics. Jisc. [Web log post]. Retrieved from http://analytics.jiscinvolve.org/wp/2015/03/03/a-taxonomy-of-ethical-legal-and-logisticalissues-of-learning-analytics-v1-0/

Sclater, N. (2015c, April 4). Explaining Jisc's open learning analytics architecture. Effective Learning Analytics. Jisc. [Web log post]. Retrieved from http://analytics.jiscinvolve.org/wp/2015/04/04/explaining-jiscs-open-learning-analyticsarchitecture/

Sclater, N. (2015d, June 4). Code of practice for learning analytics launched. Effective Learning Analytics. Jisc. [Web log post]. Retrieved from http://analytics.jiscinvolve.org/wp/2015/06/04/code-ofpractice-for-learning-analytics-launched/

Sclater, N., \& Bailey, P. (2015). Code of practice for learning analytics. Jisc. Retrieved from http://www.jisc.ac.uk/guides/code-of-practice-for-learning-analytics

Slade, S., \& Prinsloo, P. (2013). Learning analytics: Ethical issues and dilemmas. American Behavioral Scientist, 57(10), 1509-1528. http://dx.doi.org/10.1177/0002764213479366

SURF (2015). Guide to learning analytics under the personal data protection act. Retrieved from https://www.surf.nl/en/knowledge-base/2015/guide-to-learning-analytics-under-the-personaldata-protection-act.html

Swenson, J. (2014). Establishing an ethical literacy for learning analytics. Proceedings of the $4^{\text {th }}$ International Conference on Learning Analytics and Knowledge, 246-250. http://dx.doi.org/10.1145/2567574.2567613

University of Edinburgh. (2015). Learning analytics: Guidance on learning analytics and data protection. Retrieved from http://www.ed.ac.uk/records-management/data-protection/guidancepolicies/learning-analytics

Willis, J. E., III, \& Pistilli, M. D. (2014, April). Ethical discourse: Guiding the future of learning analytics. EDUCAUSE Review Online. Retrieved from http://www.educause.edu/ero/article/ethicaldiscourse-guiding-futurelearning-analytics 